\title{
Effect of ethrel on the starch sugar changes of off- season fruits of mango (mangifera indica l. Var. Neelum) during ripening
}

\author{
T. Venkatesan*, C. Tamilmani \\ Department of Botany, Annamalai University, Annamalai Nagar, Tamil Nadu, India \\ *E-mail address: dr_venkatesan75@yahoo.com
}

\begin{abstract}
The present investigation is aimed at studying the effect of ethrel on the ripening of offseason fruits of Mangifera indica L. var. Neelum. The control fruits were kept in the laboratory naturally while the experimental fruits were treated with different concentrations of ethrel (100, 200 and $300 \mathrm{ppm}$ ). In control fruits, partial ripening led to incomplete metabolic changes, which did not alter the presence of sourness in the fruits. Hence, they were not fit to be eaten. On the other hand, the fruits treated with different concentrations (100, 200 and $300 \mathrm{ppm})$ of ethrel ripened on $13^{\text {th }}$ day, $11^{\text {th }}$ day and $9^{\text {th }}$ day respectively after treatment. The colour changed from green greenish to yellow and the fruits were palatable in nature. The starch decreased during ripening, both in the treated and control fruits. On the other hand, the sugar, $\alpha$-amylase, $\beta$ amylase, activities increased. Among the different 100, 200 and $300 \mathrm{ppm}$ ethrel treatments, the $200 \mathrm{ppm}$ alone had the optimum effect on the ripening of off-season fruits of Mangifera indica L. var. Neelum.
\end{abstract}

Keywords: Starch; Sugar; amylase and fruit ripening

\section{INTRODUCTION}

Ripening in mangoes involves numerous metabolic activities leading to changes in carbohydrates and acids resulting in declined sugar, acid ratio and development of colour, flavour characteristics, and softening of the texture of acceptable quality. These changes take place in harvested fruits, within a short period of 9 to 12 days at ambient temperature, depending on the variety and stage of maturity. Each mango variety on ripening has distinct characteristics and flavour. Unlike unripe fruits which are astringent, acidic and rich in vitamin $\mathrm{C}$, the ripe fruits are sour and/ or sweet, rich in carotenoids, moderate in vitamin $\mathrm{C}$ and highly aromatic (Selvaraj, 1993). As fruits begin to soften, starch deposits are degraded and sugar and flavour components are accumulated (Bathgate et al., 1985). Hydrolysis of starch is a major event during ripening of fruits (Loesecke and Von, 1949). The breakdown of starch to glucose, fructose or sucrose is a characteristic of ripening event. There are several 
enzymes in plant tissue that are capable of metabolizing starch (Presis and Levi, 1980). Jain et al. (2003) observed that Guava Starch, which is the main storage polysaccharide in many unripe fruits, is degraded during ripening, resulting in sweetness and textural changes in fruits. Guava fruits also exhibited a decrease in starch and an increase in the content of reducing and non-reducing sugars during ripening. Starch content decreased significantly from $3.42 \%$ at MG stage to $0.90 \%$ at overripe stage. Starch content has also been reported to decrease in fruits like papaya. Thanaraj et al., (2009) observed that in Srilankan mango starch concentration was significantly higher in CV. Malgova (35\% DW) than CVS. Karutha colomban (29\% DW) and Willard (21\% DW) fruit. Even though sugar concentration was relatively low in CV. Karutha colomban as compared to CV. Willard, starch concentration was high. Starch levels varied significantly between fully mature $(38.6 \% \mathrm{DW})$ and immature stages $(19.7 \%$ DW). Mango peel $(24.4 \% \mathrm{DW})$ had a significantly lower concentration of starch than pulp tissue $(30.2 \% \mathrm{DW})$ : however, there was no noticeable difference in starch concentration between peel and pulp at immature stage. It was also noticed that the outer pulp $(31.6 \%$ DW) contained more starch than inner pulp $(28.7 \%$ DW). Dry mature as a proportion of FW increased with maturity and was significantly higher in peel (24.5-0.7 $\mathrm{g} / 100 \mathrm{~g} \mathrm{FW})$ than in pulp (16.5-31.1 g/100g FW) tissue. Mango CV. Willard had significantly lower dry matter than that of other cultivars.

The flavour of a fruit is compounded mainly of its content of sugars, acids and of numerous volatile aroma components, which are present in very small quantities but which elicit a considerable olfactory response. Changes of flavour during post-harvest ripening typically result from an increase in sugar at the expense of reserve carbohydrate, a decrease in acids, which may be respired, and considerable increase in the production of volatile aroma components (Burton, 1982). The content of sugar increase during fruit ripening was studied in detail by a number of workers (Paul and Southgate, 1978; Tandon and Kalra, 1983; Tandon et al., 1985 Tucker, 1993; Yamaki, 1995; Venkitakrishnan et al., 1997; Lester et al., 1998).

In general, after harvest the sugar content increases at the expense of starch. At the commencement of ripening, the majority of sugars are reducing in nature, but the ripe fruit contains more non-reducing than reducing sugars. In mango, mostly glucose and fructose are the reducing sugars and sucrose is the non-reducing sugar (Subramanyam et al., 1972). A decline in starch content and amylase activity was reported after 91 days of growth in Dasheri variety. Glucose and fructose were more until maturity whereas during ripening, sucrose was more plentiful (Tandon and Kalra, 1983; Kalra and Tandon, 1983). In Langra and Mailika, the total sugars, reducing sugars and fructose increased and starch decreased during ripening (Tandon et al., 1985). Sucrose, glucose and fructose were the main sugars in seven mango varieties, and their concentration increased during ripening. Sucrose content which was low at harvest maturity, increased considerably during ripening and was at a comparable level with that of fructose in the varieties, Alphonso and Suvarnarekha, and with that of glucose in Banganapalli. Changes in glucose: fructose ratio during ripening showed marked differences between varieties. It increased in the varieties, Suvarnarekha and Totapari, decreased in Alphonso, Fazli, and Dasheri and remained more or less the same in Banganapalli and Langra (Selvaraj et al., 1989). Thanaraj et al. (2009) observed that in Srilankan mango, fructose, glucose and sucrose varied significantly among cultivars. Fructose was the dominant sugar $(63.7-130 \mathrm{mg} / \mathrm{g} \mathrm{DW})$ in all cultivars and contributed to more than half of total sugar present, followed by glucose (18.6-83.6 mg/g DW) and sucrose (19.8-50.5 mg/g DW). Total sugar was highest in CV. Malgova (260 mg/g DW) followed by CV. Willard (205 mg/g DW) and CV. Ampalavi (190 mg/g DW). There was no significant variation in sugar concentration 
according to vertical sectioning (Stem end, middle and distal end). Sugar concentration was significantly lower in peel $(119 \mathrm{mg} / \mathrm{g} \mathrm{DW})$ than in pulp $(202 \mathrm{mg} / \mathrm{g} \mathrm{DW})$. However, there was no significant variation between inner and outer pulp. In general, total sugar concentration declined significantly from immature stage $(199 \mathrm{mg} / \mathrm{g} \mathrm{DW})$ to fully mature stage $(162 \mathrm{mg} / \mathrm{g}$ DW) of mango. However, sugar concentration was relatively high in the fully mature stage versus the immature of mango CVS. Willard and Ampalavi fruit. The total sugars increased from $4.76 \%$ at $\mathrm{MG}$ stage to $8.96 \%$ at OR stage. Both reducing and non-reducing sugars were present at the same concentration $(2.38 \%)$ at $\mathrm{MG}$ stage. Reducing sugars increased substantially to $5.60 \%$ at OR stage, whereas non-reducing sugars increased slightly and that also at later stages only, i.e., between ripe and overripe stages. This increase is mainly due to degradation of starch.

Sacher (1973) has reported an increase in the activity of amylase during ripening of tomato and mango. An increased amylase activity in banana during ripening was noticed by (Mao and Kinsella, 1981). In Banana, the relative activities of hydrolytic and oxidative enzymes, Viz., $\alpha$-amylase, starch phosphorylase, acid phosphorylase, Catalase and peroxidase increased in Banana varieties, Pachabale, Rasabale, and Rajabale during ripening. An upsurge in the activities of all the enzymes to a maximum of 1.2 to 19.1 times of the initial level was observed (Desai and Deshpande, 1978). The starch that has accumulated in the maturing fruit is rapidly lost during ripening (Selvaraj et al., 1989) and this loss is evident in the chloroplast where the starch granules become progressively smaller as ripening proceeds. Starch granules completely disappear in the ripe fruit (Parikh et al, 1990) which usually contains negligible levels of starch (Fuchs et al., 1980).

Starch hydrolysis in the ripening mango has been associated with amylase activity (Fuchs et al., 1980), which exhibits the properties of both $\alpha$ and $\beta$ - amylases. The complete disappearance of starch may be attributed to an upsurge of amylase as ripening is completed.

As a consequence of starch hydrolysis, total sugars increase during ripening, with glucose, fructose and sucrose constituting most of the monosaccharides (Selvaraj et al., 1989). The total sugar content of the ripe „Carabao mango is one of the highest reported, with values exceeding $20 \%$ (Peacock and Brown, 1984). However, the lower sugar contents reported for other varieties such as "Golek (Lam et al., 1982) might simply reflect differences in the degree of ripeness when optimum eating quality is attained.

$\alpha$-Amylase and $\beta$-amylase are the two amylases in plant tissues capable of metabolizing starch, $\alpha$-Amylase hydrolyze the $\alpha-1,4$-linkages of amylase at random to produce a mixture of glucose and maltose, whereas $\beta$-amylase attacks only the penultimate linkage from the non-reducing end and thus release only maltose. These enzymes are unable to degrade the $\beta$ (1-6) branch points of amylopectin, which are catalyzed by debranching enzymes. Amylase activity increases to some extent during ripening of many fruits (Fuchs et al., 1980; Tucker and Grierson, 1987). Mango and banana are the major starch containing fruits (-15 to $20 \%$, on fresh weight basis), where starch is almost completely hydrolyzed to free sugars, thus contributing to loosening of structure and textural softening during ripening by Jain et al. (2003) observed that Guava the activity of $\alpha$ and $\beta$-amylase decreased throughout the process of ripening, suggesting that perhaps the activity of these enzymes in raw guava was sufficient to hydrolyze starch during ripening which was apparent from the decrease in starch content during ripening. The highest activity of starch-hydrolyzing enzymes was associated with the highest starch concentration. The main objective of this was to look the effect of ethrel on the starch, sugar conversion and hydrolytic enzyme activity during the ripening of off-season fruits of mango. 


\section{MATERIAL AND METHODS}

The detached fruits of Mangifera indica L. var. Neelum were selected for the present study. The off-season (September to February) green mature unripe fruits were harvested from Auroville near Pondicherry union territory, India and stored in cortons in the Department of Botany at room temperature $28 \pm 2{ }^{\circ} \mathrm{C}$ with the relative humidity of 85 per cent. They were treated with different concentrations of ethrel $(100,200$ and 300 ppm). All the experiments were conducted with seven replicates. The peel and pulp of the fruit material were used to study the ripening process. Starch was extracted and estimated, using the method of Clegg (1956). The residue left behind after the alcoholic extract of the material was taken for starch extraction and estimation. Starch was solubilized with 52 per cent perchloric acid for 50 minutes, filtered, and was made upto $100 \mathrm{ml}$ in a volumetric flask, with distilled water. One to two $\mathrm{ml}$ of the perchloric acid extract was diluted with $5 \mathrm{ml}$ of deionised water in test tube and $10 \mathrm{ml}$ of anthrone reagent was added in cold. The contents were heated for 7.5 minutes at $100{ }^{\circ} \mathrm{C}$ in a boiling water bath. The test tubes were cooled rapidly and the colour intensity was read at $630 \mathrm{~nm}$ in a Spectronic - 20. The starch content was calculated, using a standard graph prepared with glucose. Soluble sugars, reducing and non-reducing sugars, were estimated following the method of Nelson (1944). Two $g$ of fruit material was macerated in a mortar and pestle with 80 per cent ethyl alcohol. The homogenate was centrifuged at $800 \mathrm{rpm}$ for 15 minutes. The supernatant was saved and made upto $20 \mathrm{ml}$ with 80 per cent ethyl alcohol. This extract was used to estimate both reducing and non-reducing sugars. To $1 \mathrm{ml}$ of ethanolic extract, $1 \mathrm{ml}$ of fresh Nelson's reagent (prepared by mixing copper tartrate solution and copper sulphate solution 25:1 (v/v) was added. The mixture was heated in boiling water for 20 minutes, and then cooled. To the cooled mixture, $1 \mathrm{ml}$ of Nelson's Arsenomolybdate reagent was added. The solution was diluted to $25 \mathrm{ml}$ with distilled water. The intensity of the resulting blue colour was read at $520 \mathrm{~nm}$ in a Spectronic -20 . The content of the reducing sugar was calculated from glucose standard graph.

Non-reducing sugars were hydrolysed to reducing sugars, and the total sugar was estimated. One $\mathrm{ml}$ of ethanolic extract was evaporated to dryness in a boiling water bath. To the residue, $1 \mathrm{ml}$ of distilled water and $1 \mathrm{ml}$ of concentrated $\mathrm{H}_{2} \mathrm{SO}_{4}$ were added. The mixture was hydrolysed by incubating in an oven at $50{ }^{\circ} \mathrm{C}$ for 30 minutes. The solution was neutralized with $1 \mathrm{~N} \mathrm{NaOH}$. Total sugar of the hydrolyzed sample was estimated by using Nelson's Arsenomolybdate method. Non-reducing sugar content was calculated by substracting the value of reducing sugar from the total sugar.

$\alpha$-amylase and $\beta$-amylase activities were assayed, using the modified method of Danielson (1947) and Englard and Singer (1950). Enzyme extraction $1 \mathrm{~g}$ of the fruit material was homogenized in a prechilled mortar and pestle with $20 \mathrm{ml}$ of distilled water. The homogenate was centrifuged at $24,000 \mathrm{rpm}$ for 30 minutes at $4{ }^{\circ} \mathrm{C}$ in a refrigated centrifuge. The supernatant was saved and it was used as an enzyme source. To the $0.5 \mathrm{ml}$ of the enzyme extract, $1 \mathrm{ml}$ of $0.1 \mathrm{M}$ citrate buffer $(\mathrm{pH} \mathrm{5.0)}$ and $0.5 \mathrm{ml}$ of 2 per cent soluble starch was added. The reaction was allowed for 5 minutes after the addition of starch at $30{ }^{\circ} \mathrm{C}$. After 5 minutes, the reaction was stopped by adding $2 \mathrm{ml}$ of colour reagent. The mixture was boiled for 5 minutes in a water bath at $50{ }^{\circ} \mathrm{C}$. After cooling, the final volume of the solution was made upto $10 \mathrm{ml}$ with distilled water. The absorbance was read at $540 \mathrm{~nm}$ in a Spectronic-20. $\alpha$-amylase activity was assayed by adding $1 \mathrm{ml}$ of $0.1 \mathrm{M}$ citrate buffer ( $\mathrm{pH} \mathrm{3.4)}$ ) and $0.5 \mathrm{ml}$ of 2 per cent starch to the $0.5 \mathrm{ml}$ of the enzyme extract. The reaction was allowed for 5 minutes. Then the reaction was stopped by adding 
$2 \mathrm{ml}$ of the colour reagent and the final volume was made upto $10 \mathrm{ml}$ with distilled water. The colour intensity was read at $640 \mathrm{~nm}$ in Spectronic -20 .

\section{RESULTS AND DISCUSSION}

The Table 1 shows the changes in starch content, which occur during the ripening of Mangifera indica fruits. The total starch content gradually decreased in the treated fruits, while control fruits retained certain amount of starch during the course of ripening. The starch content was more in control than in treated fruits.

Table 1. Effect of ethrel on the starch changes during the ripening of off-season fruits of Mangifera indica L. var. Neelum.

(Values are Mean \pm SE of 7 samples expressed in $\mathrm{mg}$. Glucose equivalent/g fr. wt.)

\begin{tabular}{|c|c|c|c|c|c|c|c|c|}
\hline \multirow{4}{*}{ Days } & \multicolumn{9}{|c|}{ Peel } & \multicolumn{4}{c|}{ Pulp } \\
\cline { 2 - 9 } & Control & $\mathbf{1 0 0} \mathbf{~ p p m}$ & $\mathbf{2 0 0} \mathbf{~ p p m}$ & $\mathbf{3 0 0} \mathbf{~ p p m}$ & Control & $\mathbf{1 0 0} \mathbf{~ p p m}$ & $\mathbf{2 0 0} \mathbf{~ p p m}$ & $\mathbf{3 0 0} \mathbf{~ p p m}$ \\
\cline { 2 - 9 } & Mean \pm SE & Mean \pm SE & Mean \pm SE & Mean \pm SE & Mean \pm SE & Mean \pm SE & Mean \pm SE & Mean \pm SE \\
\hline \multirow{2}{*}{1} & 0.115 & 0.108 & 0.102 & 0.090 & 0.105 & 0.096 & 0.092 & 0.080 \\
& \pm 0.009 & \pm 0.008 & \pm 0.008 & \pm 0.007 & \pm 0.008 & \pm 0.008 & \pm 0.007 & \pm 0.006 \\
\hline \multirow{2}{*}{3} & 0.095 & 0.078 & 0.086 & 0.072 & 0.086 & 0.067 & 0.067 & 0.063 \\
& \pm 0.007 & \pm 0.005 & \pm 0.006 & \pm 0.005 & \pm 0.006 & \pm 0.005 & \pm 0.005 & \pm 0.004 \\
\hline \multirow{2}{*}{5} & 0.086 & 0.074 & 0.076 & 0.069 & 0.074 & 0.062 & 0.062 & 0.058 \\
& \pm 0.005 & \pm 0.004 & \pm 0.005 & \pm 0.004 & \pm 0.004 & \pm 0.004 & \pm 0.004 & \pm 0.003 \\
\hline \multirow{2}{*}{7} & 0.075 & 0.070 & 0.062 & 0.066 & 0.064 & 0.056 & 0.050 & 0.054 \\
& \pm 0.004 & \pm 0.004 & \pm 0.003 & \pm 0.003 & \pm 0.003 & \pm 0.003 & \pm 0.003 & \pm 0.003 \\
\hline \multirow{2}{*}{9} & 0.070 & 0.066 & 0.056 & 0.062 & 0.062 & 0.054 & 0.048 & 0.050 \\
& \pm 0.005 & \pm 0.005 & \pm 0.004 & \pm 0.004 & \pm 0.005 & \pm 0.004 & \pm 0.004 & \pm 0.004 \\
\hline \multirow{2}{*}{11} & 0.066 & 0.062 & 0.048 & 0.056 & 0.058 & 0.052 & 0.036 & 0.048 \\
& \pm 0.005 & \pm 0.004 & \pm 0.003 & \pm 0.004 & \pm 0.004 & \pm 0.004 & \pm 0.003 & \pm 0.003 \\
\hline \multirow{2}{*}{13} & 0.058 & 0.052 & 0.036 & 0.048 & 0.049 & 0.046 & 0.028 & 0.034 \\
& \pm 0.003 & \pm 0.003 & \pm 0.002 & \pm 0.003 & \pm 0.003 & \pm 0.003 & \pm 0.002 & \pm 0.002 \\
\hline \multirow{2}{*}{15} & 0.046 & 0.042 & 0.028 & 0.036 & 0.038 & 0.034 & 0.018 & 0.026 \\
& \pm 0.002 & \pm 0.002 & \pm 0.001 & \pm 0.002 & \pm 0.002 & \pm 0.002 & \pm 0.001 & \pm 0.001 \\
\hline
\end{tabular}

The content of starch decreased was more in the pulp than in the peel, both in the treated and control fruits. The percentage of loss was more in the $200 \mathrm{ppm}$ ethrel treated fruits than in the 100,300 ppm and control. As fruits began to soften, starch deposits degraded and sugar and flavour components accumulated (Bathgate et al., 1985). Hydrolysis of starch was a major event during the ripening of fruits (Loesecke and Von 1949). The breakdown of starch to glucose, fructose or sucrose, is a characteristic of ripening event. There are several enzymes in plant tissue, capable of metabolizing starch (Presis and Levi, 1980). In banana, the green and unripe fruits are rich in reserve 
carbohydrate in the form of starch. During ripening, almost entire starch is converted into simple sugars, such as sucrose, fructose and glucose. Only 1-2 per cent of starch remains in the ripe fruits similarly certain amount of starch remains in the ripened off-season fruit of Mangifera indica. The retained starch content was higher in the control fruits than in the treated fruits. Hence, the untreated fruits are not suitable for edible purposes because of high sourness and rich amount of starch. On the other hand, hydrolysis of starch is more in the treated fruits; comparably the content of sugar also increases. Hence it is suitable for edible purposes. Jain et al. (2003) observed that guava starch, which is the main storage polysaccharide in many unripe fruits, is degraded during ripening, resulting in sweetness and textural changes in fruits. Guava fruits also exhibited a decrease in starch and an increase in the content of reducing and non-reducing sugars during ripening. Starch content decreased significantly from $3.42 \%$ at $\mathrm{MG}$ stage to $0.90 \%$ at overripe stage. Thanaraj et al. (2009) observed that Srilankan mangoes starch concentration was significantly higher in CV. Malgova (35 \% DW) than in CV. Karutha colomban (29\% DW) and Willard $(21 \%$ DW) fruits. Even though sugar concentration was relatively low in CV. Karutha colomban as compared to CV. Willard, starch concentration was high. Starch levels varied significantly between fully mature $(38.6 \% \mathrm{DW})$ and immature stages $(19.7 \% \mathrm{DW})$. Mango peel $(24.4 \% \mathrm{DW})$ had a significantly lower concentration of starch than pulp tissue $(30.2 \%$ DW): however, there was no noticeable difference in starch concentration between peel and pulp at immature stage. It was also noticed that the outer pulp $(31.6 \% \mathrm{DW})$ contained more starch than inner pulp $(28.7 \%$ DW). Dry mature as a proportion of FW increased with maturity and was significantly higher in peel (24.5-50.7 g/100g FW) than in pulp (16.5-31.1 $\mathrm{g} / 100 \mathrm{~g} \mathrm{FW}$ ) tissue. Mango CV. Willard had significantly lower dry matter than that of other cultivars. The Tables 2, 2(a) and 2(b) show the changes in sugar, which occur during the ripening of Mangifera indica fruits.

Table 2. Effect of ethrel on the reducing sugar changes during the ripening of off-season fruits of Mangifera indica L. var. Neelum.

(Values are Mean \pm SE of 7 samples expressed in $\mathrm{mg}$. Glucose equivalent/g fr. wt.)

\begin{tabular}{|c|c|c|c|c|c|c|c|c|}
\hline \multirow{3}{*}{ Days } & \multicolumn{9}{|c}{ Peel } & \multicolumn{4}{c|}{ Pulp } \\
\cline { 2 - 9 } & Control & $\mathbf{1 0 0 ~ p p m}$ & $\mathbf{2 0 0} \mathbf{~ p p m}$ & $\mathbf{3 0 0} \mathbf{~ p p m}$ & Control & $\mathbf{1 0 0} \mathbf{~ p m}$ & $\mathbf{2 0 0} \mathbf{~ p p m}$ & $\mathbf{3 0 0} \mathbf{~ p p m}$ \\
\hline \multirow{2}{*}{1} & 0.338 & 0.330 & 0.335 & 0.329 & 0.365 & 0.359 & 0.355 & 0.372 \\
& \pm 0.027 & \pm 0.026 & \pm 0.027 & \pm 0.026 & \pm 0.029 & \pm 0.029 & \pm 0.028 & \pm 0.030 \\
\hline \multirow{2}{*}{3} & 0.344 & 0.338 & 0.340 & 0.0336 & 0.370 & 0.369 & 0.358 & 0.376 \\
& \pm 0.024 & \pm 0.024 & \pm 0.024 & \pm 0.023 & \pm 0.026 & \pm 0.026 & \pm 0.025 & \pm 0.026 \\
\hline \multirow{2}{*}{5} & 0.352 & 0.343 & 0.349 & 0.341 & 0.380 & 0.349 & 0.343 & 0.386 \\
& \pm 0.021 & \pm 0.021 & \pm 0.021 & \pm 0.020 & \pm 0.023 & \pm 0.021 & \pm 0.021 & \pm 0.023 \\
\hline \multirow{2}{*}{7} & 0.368 & 0.366 & 0.370 & 0.364 & 0.402 & 0.396 & 0.390 & 0.406 \\
& \pm 0.018 & \pm 0.018 & \pm 0.019 & \pm 0.018 & \pm 0.020 & \pm 0.020 & \pm 0.020 & \pm 0.020 \\
\hline \multirow{2}{*}{9} & 0.386 & 0.390 & 0.393 & 0.389 & 0.429 & 0.424 & 0.410 & 0.430 \\
& \pm 0.031 & \pm 0.031 & \pm 0.031 & \pm 0.031 & \pm 0.034 & \pm 0.034 & \pm 0.033 & \pm 0.034 \\
\hline \multirow{2}{*}{11} & 0.410 & 0.415 & 0.419 & 0.409 & 0.449 & 0.438 & 0.435 & 0.452 \\
& \pm 0.029 & \pm 0.029 & \pm 0.029 & \pm 0.029 & \pm 0.031 & \pm 0.031 & \pm 0.030 & \pm 0.032 \\
\hline \multirow{2}{*}{13} & 0.426 & 0.420 & 0.426 & 0.411 & 0.450 & 0.449 & 0.445 & 0.452 \\
& \pm 0.026 & \pm 0.025 & \pm 0.026 & \pm 0.025 & \pm 0.027 & \pm 0.027 & \pm 0.027 & \pm 0.027 \\
\hline \multirow{2}{*}{15} & 0.442 & 0.426 & 0.432 & 0.419 & 0.468 & 0.459 & 0.448 & 0.470 \\
& \pm 0.022 & \pm 0.021 & \pm 0.022 & \pm 0.021 & \pm 0.024 & \pm 0.023 & \pm 0.022 & \pm 0.024 \\
\hline
\end{tabular}


Table 2(a). Effect of ethrel on the non-reducing sugar changes during the ripening of off-season fruits of Mangifera indica

L. var. Neelum

(Values are Mean \pm SE of 7 samples expressed in $\mathrm{mg}$. Glucose equivalent/g fr. wt.)

\begin{tabular}{|c|c|c|c|c|c|c|c|c|}
\hline \multirow{3}{*}{ Days } & \multicolumn{9}{|c}{ Peel } & \multicolumn{4}{c|}{ Pulp } \\
\cline { 2 - 9 } & \multirow{2}{*}{ Control } & $\mathbf{1 0 0} \mathbf{~ p p m}$ & $\mathbf{2 0 0} \mathbf{~ p p m}$ & $\mathbf{3 0 0} \mathbf{~ p p m}$ & Control & $\mathbf{1 0 0} \mathbf{~ p p m}$ & $\mathbf{2 0 0} \mathbf{~ p p m}$ & $\mathbf{3 0 0} \mathbf{~ p p m}$ \\
\hline \multirow{2}{*}{1} & 0.342 & 0.338 & 0.349 & 0.336 & 0.378 & 0.380 & 0.376 & 0.385 \\
& \pm 0.027 & \pm 0.027 & \pm 0.028 & \pm 0.027 & \pm 0.030 & \pm 0.030 & \pm 0.030 & \pm 0.031 \\
\hline \multirow{2}{*}{3} & 0.348 & 0.346 & 0.352 & 0.344 & 0.384 & 0.372 & 0.380 & 0.382 \\
& \pm 0.024 & \pm 0.024 & \pm 0.025 & \pm 0.024 & \pm 0.027 & \pm 0.026 & \pm 0.027 & \pm 0.027 \\
\hline \multirow{2}{*}{5} & 0.359 & 0.356 & 0.360 & 0.348 & 0.400 & 0.396 & 0.392 & 0.398 \\
& \pm 0.021 & \pm 0.021 & \pm 0.022 & \pm 0.021 & \pm 0.024 & \pm 0.024 & \pm 0.024 & \pm 0.024 \\
\hline \multirow{2}{*}{7} & 0.380 & 0.378 & 0.382 & 0.372 & 0.428 & 0.412 & 0.412 & 0.418 \\
& \pm 0.019 & \pm 0.019 & \pm 0.019 & \pm 0.019 & \pm 0.022 & \pm 0.020 & \pm 0.020 & \pm 0.021 \\
\hline \multirow{2}{*}{9} & 0.398 & 0.397 & 0.408 & 0.394 & 0.442 & 0.428 & 0.424 & 0.435 \\
& \pm 0.032 & \pm 0.032 & \pm 0.033 & \pm 0.031 & \pm 0.036 & \pm 0.034 & \pm 0.034 & \pm 0.035 \\
\hline \multirow{2}{*}{11} & 0.425 & 0.426 & 0.439 & 0.421 & 0.466 & 0.455 & 0.451 & 0.460 \\
& \pm 0.030 & \pm 0.029 & \pm 0.030 & \pm 0.029 & \pm 0.032 & \pm 0.032 & \pm 0.032 & \pm 0.033 \\
\hline \multirow{2}{*}{13} & 0.436 & 0.428 & 0.444 & 0.422 & 0.482 & 0.465 & 0.455 & 0.472 \\
& \pm 0.026 & \pm 0.026 & \pm 0.026 & \pm 0.025 & \pm 0.029 & \pm 0.028 & \pm 0.027 & \pm 0.028 \\
\hline \multirow{2}{*}{15} & 0.439 & 0.432 & 0.436 & 0.429 & 0.486 & 0.471 & 0.461 & 0.478 \\
& \pm 0.022 & \pm 0.022 & \pm 0.022 & \pm 0.021 & \pm 0.024 & \pm 0.024 & \pm 0.023 & \pm 0.023 \\
\hline
\end{tabular}

Table 2(b). Effect of ethrel on the total sugar changes during the ripening of off-season fruits of Mangifera indica L. var. Neelum

(Values are Mean \pm SE of 7 samples expressed in $\mathrm{mg}$. Glucose equivalent/g fr. wt.)

\begin{tabular}{|c|c|c|c|c|c|c|c|c|}
\hline \multirow{3}{*}{ Days } & \multicolumn{9}{|c|}{ Peel } & \multicolumn{4}{c|}{ Pulp } \\
\cline { 2 - 9 } & Control & $\mathbf{1 0 0} \mathbf{~ p p m}$ & $\mathbf{2 0 0} \mathbf{~ p p m}$ & $\mathbf{3 0 0} \mathbf{~ p p m}$ & Control & $\mathbf{1 0 0} \mathbf{~ p p m}$ & $\mathbf{2 0 0} \mathbf{~ p p m}$ & $\mathbf{3 0 0} \mathbf{~ p p m}$ \\
\hline \multirow{2}{*}{1} & 0.677 & 0.668 & 0.665 & 0.687 & 0.731 & 0.739 & 0.750 & 0.750 \\
& \pm 0.054 & \pm 0.053 & \pm 0.053 & \pm 0.055 & \pm 0.058 & \pm 0.059 & \pm 0.060 & \pm 0.060 \\
\hline \multirow{2}{*}{3} & 0.688 & 0.684 & 0.680 & 0.696 & 0.738 & 0.741 & 0.752 & 0.760 \\
& \pm 0.048 & \pm 0.048 & \pm 0.047 & \pm 0.049 & \pm 0.052 & \pm 0.052 & \pm 0.053 & \pm 0.053 \\
\hline \multirow{2}{*}{5} & 0.708 & 0.699 & 0.689 & 0.710 & 0.735 & 0.745 & 0.778 & 0.786 \\
& \pm 0.042 & \pm 0.042 & \pm 0.041 & \pm 0.043 & \pm 0.045 & \pm 0.045 & \pm 0.047 & \pm 0.047 \\
\hline \multirow{2}{*}{7} & 0.750 & 0.744 & 0.736 & 0.750 & 0.802 & 0.808 & 0.820 & 0.834 \\
& \pm 0.038 & \pm 0.037 & \pm 0.037 & \pm 0.037 & \pm 0.040 & \pm 0.040 & \pm 0.041 & \pm 0.042 \\
\hline \multirow{2}{*}{9} & 0.791 & 0.787 & 0.783 & 0.794 & 0.834 & 0.852 & 0.864 & 0.872 \\
& \pm 0.063 & \pm 0.063 & \pm 0.062 & \pm 0.064 & \pm 0.067 & \pm 0.068 & \pm 0.069 & \pm 0.070 \\
\hline \multirow{2}{*}{11} & 0.844 & 0.841 & 0.830 & 0.849 & 0.886 & 0.893 & 0.909 & 0.918 \\
& \pm 0.059 & \pm 0.058 & \pm 0.058 & \pm 0.059 & \pm 0.062 & \pm 0.063 & \pm 0.064 & \pm 0.064 \\
\hline \multirow{2}{*}{13} & 0.862 & 0.848 & 0.833 & 0.870 & 0.900 & 0.914 & 0.922 & 0.934 \\
& \pm 0.052 & \pm 0.051 & \pm 0.050 & \pm 0.052 & \pm 0.054 & \pm 0.055 & \pm 0.055 & \pm 0.056 \\
\hline \multirow{2}{*}{15} & 0.871 & 0.858 & 0.848 & 0.878 & 0.929 & 0.930 & 0.946 & 0.956 \\
& \pm 0.044 & \pm 0.043 & \pm 0.042 & \pm 0.044 & \pm 0.045 & \pm 0.047 & \pm 0.047 & \pm 0.048 \\
\hline
\end{tabular}


The reducing sugar, non-reducing sugar and total sugar content gradually increased during the course of ripening, both in the control and treated fruits. The content of sugar was more in the treated fruits than in the control fruits. The non-reducing sugar content was more than that of reducing sugars in the peel and the pulp of the treated and control fruits. The content of sugar was more in the pulp than in the peel during the ripening process. The statistical analysis on starch and total sugar in the peel and pulp, both in the control and treated, showed a negative correlation. The correlation co-efficient values were - 0.93. - 0.87, - 0.92, - 0.96, - 0.90, - 0.82, - 0.92 and - 0.95. The observed correlation co-efficient values were significant at $1 \%$ level. In general, after harvest, the sugar content increases at the expense of starch. At the commencement of ripening, the majority of sugars are reducing in nature, but the ripe fruit contains more non-reducing than reducing sugars. In mango, mostly glucose and fructose are the reducing sugars and sucrose is the non-reducing sugar (Subramanyam et al., 1972). Similarly Thanaraj (2009) reported that in Srilankan Mango the fructose, glucose and sucrose varied significantly among cultivars. Fructose was the dominant sugar $(63.7-130 \mathrm{mg} / \mathrm{g} \mathrm{DW})$ in all cultivars and contributed to more than half of total sugar present, followed by glucose $(18.6-83.6 \mathrm{mg} / \mathrm{g}$ DW) and sucrose (19.8-50.5 mg/g DW). Total sugar was highest in CV. Malgova $(260 \mathrm{mg} / \mathrm{g}$ DW) followed by CV. Willard (205 mg/g DW) and CV. Ampalavi (190 mg/g DW). There was no significant variation in sugar concentration according to vertical sectioning (Stem end, middle and distal end). Sugar concentration was significantly lower in peel (119 mg/g DW) than in pulp (202 mg/g DW). However, there was no significant variation between inner and outer pulp. In general, total sugar concentration declined significantly from immature stage (199 mg/g DW) to fully mature stage $(162 \mathrm{mg} / \mathrm{g} \mathrm{DW})$ of mango. However, sugar concentration was relatively high in the fully mature stage versus the immature of mango CVS. Willard and Ampalavi fruit. The total sugars increased from $4.76 \%$ at MG stage to $8.96 \%$ at OR stage. Both reducing and non-reducing sugars were present at the same concentration $(2.38 \%)$ at MG stage. Reducing sugars increased substantially to $5.60 \%$ at OR stage, whereas non-reducing sugars increased slightly and that also at later stages only, i.e., between ripe and overripe stages. This increase is mainly due to degradation of starch. A decline in starch content and amylase activity was reported after 91 days of growth in the variety, Dasheri. Glucose and fructose were more until maturity, whereas during ripening, sucrose was more plentiful (Tandon and Kalra, 1983; Kalra and Tandon, 1983). In the Langra and Mailika, the total sugars, reducing sugars and fructose increased and starch decreased during ripening (Tandon et al., 1985). Similar findings were observed in the off-season fruits of Mangifera indica. Sucrose, glucose, and fructose were the main sugars in seven mango varieties and their concentration increased during ripening. Sucrose content that was low in the fruits harvested at maturity increased considerably during ripening, and was at a comparable level with that of fructose in the varieties Alphonso and Suvarnarekha and with that of glucose in Banganapalli. Changes in glucose: fructose ratio during ripening showed marked differences between varieties. It increased in the varieties Suvarnarekha and Totapari, decreased in Alphonso, Fazli and Dasheri, and remained more or less the same in Banganapalli and Langra (Selvaraj et al., 1989). In mango, sweetness was more due to the presence of the high amount of non-reducing sugar than that of reducing sugar. As the content of starch decreased, the level of reducing and non-reducing sugars increased. The statistical analysis of results on starch and sugar during ripening showed negative correlation. The correlation co-efficient values are highly significant at 1 per cent level. The increase in the sugar was also coupled with the increase in the activity of the enzyme amylase. The disappearance of starch is one of the most dramatic chemical changes associated with the 
ripening of many fruits. Starch breakdown can occur either by phosphorylysis catalysed starch phosphorylase or by hydrolysis catalysed by the enzyme amylase. Both may be involved in senescent sweetening of fruits, for example potato (Burton, 1982). In Mangifera indica fruit the activity of $\alpha$-amylase and $\beta$-amylase gradually increased, both in the peel and the pulp of the treated and control fruits. The pulp had more $\alpha, \beta$-amylase activity than that of the peel, while the $\alpha$-amylase of activity was more than $\beta$-amylase activity during the course of ripening, both in the treated and control fruits. Among the treated fruits, the fruits had more activity of $\alpha$ and $\beta$-amylase in the fruits treated with $200 \mathrm{ppm}$ ethrel than in the $100,300 \mathrm{ppm}$ and control. (Tables 3 and 4). Of these two hydrolytic enzymes $\alpha$-amylase and $\beta$-amylase, the $\alpha$-amylase activity was more than the $\beta$-amylase. Hence, the $\alpha$-amylase is a key enzyme in the starch breakdown of Mangifera indica fruit. Similar increase of amylase activity in banana was noticed by Mao and Kinsella (1981).

Table 3. Effect of ethrel on the $\alpha$ - amylase changes during the ripening of off-season fruits of Mangifera indica L. var. Neelum.

(Values are Mean \pm SE of 7 samples expressed in maltose equivalent $\mathrm{mg} / / \mathrm{g}$ fr. wt)

\begin{tabular}{|c|c|c|c|c|c|c|c|c|}
\hline \multirow{3}{*}{ Days } & \multicolumn{4}{|c|}{ Peel } & \multicolumn{4}{|c|}{ Pulp } \\
\hline & Control & 100 ppm & 200 ppm & 300 ppm & Control & 100 ppm & 200 ppm & 300 ppm \\
\hline & Mean \pm SE & Mean \pm SE & Mean \pm SE & Mean \pm SE & Mean \pm SE & Mean \pm SE & Mean \pm SE & Mean $\pm \mathrm{SE}$ \\
\hline 1 & $\begin{array}{c}11.33 \\
\pm 0.906\end{array}$ & $\begin{array}{c}11.28 \\
\pm 0.902\end{array}$ & $\begin{array}{c}11.44 \\
\pm 0.915\end{array}$ & $\begin{array}{r}11.36 \\
\pm 0.909\end{array}$ & $\begin{array}{c}21.57 \\
\pm 1.726\end{array}$ & $\begin{array}{c}21.58 \\
\pm 1.726\end{array}$ & $\begin{array}{r}21.57 \\
\pm 1.726\end{array}$ & $\begin{array}{c}21.58 \\
\pm 1.726\end{array}$ \\
\hline 3 & $\begin{array}{c}12.58 \\
\pm 0.881\end{array}$ & $\begin{array}{c}13.16 \\
\pm 0.921\end{array}$ & $\begin{array}{r}15.56 \\
\pm 1.089\end{array}$ & $\begin{array}{c}14.36 \\
\pm 1.005\end{array}$ & $\begin{array}{c}22.16 \\
\pm 1.551\end{array}$ & $\begin{array}{c}22.26 \\
\pm 1.558\end{array}$ & $\begin{array}{c}22.38 \\
\pm 1.566\end{array}$ & $\begin{array}{c}22.45 \\
\pm 1.572\end{array}$ \\
\hline 5 & $\begin{array}{c}13.16 \\
\pm 0.790\end{array}$ & $\begin{array}{c}14.26 \\
\pm 0.856\end{array}$ & $\begin{array}{c}19.74 \\
\pm 1.184\end{array}$ & $\begin{array}{c}15.34 \\
\pm 0.920\end{array}$ & $\begin{array}{c}23.18 \\
\pm 1.391\end{array}$ & $\begin{array}{c}23.88 \\
\pm 1.433\end{array}$ & $\begin{array}{c}23.18 \\
\pm 1.391\end{array}$ & $\begin{array}{c}24.46 \\
\pm 1.468\end{array}$ \\
\hline 7 & $\begin{array}{c}15.28 \\
\pm 0.764\end{array}$ & $\begin{array}{c}16.36 \\
\pm 0.818\end{array}$ & $\begin{array}{c}25.96 \\
\pm 1.298\end{array}$ & $\begin{array}{c}19.26 \\
\pm 0.963\end{array}$ & $\begin{array}{c}25.16 \\
\pm 1.258\end{array}$ & $\begin{array}{c}25.82 \\
\pm 1.291\end{array}$ & $\begin{array}{c}25.16 \\
\pm 1.258\end{array}$ & $\begin{array}{c}28.42 \\
\pm 1.421\end{array}$ \\
\hline 9 & $\begin{array}{c}17.32 \\
\pm 1.386\end{array}$ & $\begin{array}{c}18.21 \\
\pm 1.457\end{array}$ & $\begin{array}{c}27.42 \\
\pm 2.194\end{array}$ & $\begin{array}{c}22.24 \\
\pm 1.780\end{array}$ & $\begin{array}{c}27.81 \\
\pm 2.225\end{array}$ & $\begin{array}{c}28.16 \\
\pm 2.253\end{array}$ & $\begin{array}{c}31.66 \\
\pm 2.533\end{array}$ & $\begin{array}{c}35.78 \\
\pm 2.862\end{array}$ \\
\hline 11 & $\begin{array}{c}20.45 \\
\pm 1.432\end{array}$ & $\begin{array}{c}20.84 \\
\pm 1.458\end{array}$ & $\begin{array}{c}30.65 \\
\pm 2.145\end{array}$ & $\begin{array}{c}23.24 \\
\pm 1.627\end{array}$ & $\begin{array}{c}30.56 \\
\pm 2.139\end{array}$ & $\begin{array}{c}33.75 \\
\pm 2.362\end{array}$ & $\begin{array}{c}41.94 \\
\pm 2.936\end{array}$ & $\begin{array}{c}36.18 \\
\pm 2.533\end{array}$ \\
\hline 13 & $\begin{array}{c}23.36 \\
\pm 1.401\end{array}$ & $\begin{array}{c}23.86 \\
\pm 1.431\end{array}$ & $\begin{array}{c}32.36 \\
\pm 1.942\end{array}$ & $\begin{array}{c}24.16 \\
\pm 1.449\end{array}$ & $\begin{array}{c}33.68 \\
\pm 2.021\end{array}$ & $\begin{array}{c}34.18 \\
\pm 2.050\end{array}$ & $\begin{array}{c}47.92 \\
\pm 2.876\end{array}$ & $\begin{array}{c}40.16 \\
\pm 2.409\end{array}$ \\
\hline 15 & $\begin{array}{c}26.46 \\
\pm 1.323\end{array}$ & $\begin{array}{c}26.76 \\
\pm 1.338\end{array}$ & $\begin{array}{c}34.14 \\
\pm 1.707\end{array}$ & $\begin{array}{c}28.46 \\
\pm 1.423\end{array}$ & $\begin{array}{c}36.54 \\
\pm 1.827\end{array}$ & $\begin{array}{c}40.26 \\
\pm 2.013\end{array}$ & $\begin{array}{c}54.14 \\
\pm 2.707\end{array}$ & $\begin{array}{c}46.28 \\
\pm 2.314\end{array}$ \\
\hline
\end{tabular}


Table 4. Effect of ethrel on the $\beta$ amylase changes during the ripening of off-season fruits of Mangifera indica L. var. Neelum.

(Values are Mean \pm SE of 7 samples expressed in maltose equivalent $\mathrm{mg} / \mathrm{g}$ fr. wt)

\begin{tabular}{|c|c|c|c|c|c|c|c|c|}
\hline \multirow{3}{*}{ Days } & \multicolumn{4}{|c|}{ Peel } & \multicolumn{4}{|c|}{ Pulp } \\
\hline & Control & 100 ppm & 200 ppm & 300 ppm & Control & 100 ppm & 200 ppm & 300 ppm \\
\hline & Mean \pm SE & Mean \pm SE & Mean \pm SE & Mean \pm SE & Mean \pm SE & Mean \pm SE & Mean \pm SE & Mean \pm SE \\
\hline 1 & $\begin{array}{c}10.62 \\
\pm 0.849\end{array}$ & $\begin{array}{c}10.42 \\
\pm 0.834\end{array}$ & $\begin{array}{c}10.84 \\
\pm 0.867\end{array}$ & $\begin{array}{c}10.34 \\
\pm 0.827\end{array}$ & $\begin{array}{c}11.58 \\
\pm 0.926\end{array}$ & $\begin{array}{c}11.72 \\
\pm 0.938\end{array}$ & $\begin{array}{c}11.84 \\
\pm 0.947\end{array}$ & $\begin{array}{c}11.82 \\
\pm 0.946\end{array}$ \\
\hline 3 & $\begin{array}{r}11.82 \\
\pm 0.827\end{array}$ & $\begin{array}{c}11.32 \\
\pm 0.792\end{array}$ & $\begin{array}{r}12.56 \\
\pm 0.879\end{array}$ & $\begin{array}{r}14.40 \\
\pm 1.008\end{array}$ & $\begin{array}{c}12.23 \\
\pm 0.856\end{array}$ & $\begin{array}{r}12.26 \\
\pm 0.858\end{array}$ & $\begin{array}{c}12.78 \\
\pm 0.895\end{array}$ & $\begin{array}{c}12.60 \\
\pm 0.882\end{array}$ \\
\hline 5 & $\begin{array}{c}12.56 \\
\pm 0.754\end{array}$ & $\begin{array}{c}12.41 \\
\pm 0.745\end{array}$ & $\begin{array}{c}14.84 \\
\pm 0.890\end{array}$ & $\begin{array}{c}13.48 \\
\pm 0.809\end{array}$ & $\begin{array}{c}15.34 \\
\pm 0.920\end{array}$ & $\begin{array}{c}16.46 \\
\pm 0.988\end{array}$ & $\begin{array}{c}20.86 \\
\pm 1.252\end{array}$ & $\begin{array}{c}19.46 \\
\pm 1.168\end{array}$ \\
\hline 7 & $\begin{array}{c}14.48 \\
\pm 0.724\end{array}$ & $\begin{array}{c}14.52 \\
\pm 0.726\end{array}$ & $\begin{array}{c}16.68 \\
\pm 0.834\end{array}$ & $\begin{array}{c}15.42 \\
\pm 0.771\end{array}$ & $\begin{array}{c}19.26 \\
\pm 0.963\end{array}$ & $\begin{array}{c}20.16 \\
\pm 1.008\end{array}$ & $\begin{array}{c}23.48 \\
\pm 1.174\end{array}$ & $\begin{array}{c}21.36 \\
\pm 1.068\end{array}$ \\
\hline 9 & $\begin{array}{r}15.86 \\
\pm 1.269\end{array}$ & $\begin{array}{c}15.82 \\
\pm 1.265\end{array}$ & $\begin{array}{c}18.86 \\
\pm 1.508\end{array}$ & $\begin{array}{r}17.56 \\
\pm 1.405\end{array}$ & $\begin{array}{c}21.18 \\
\pm 1.694\end{array}$ & $\begin{array}{c}22.46 \\
\pm 1.797\end{array}$ & $\begin{array}{c}28.56 \\
\pm 2.285\end{array}$ & $\begin{array}{c}25.48 \\
\pm 2.038\end{array}$ \\
\hline 11 & $\begin{array}{c}17.88 \\
\pm 1.252\end{array}$ & $\begin{array}{c}16.62 \\
\pm 1.163\end{array}$ & $\begin{array}{c}20.16 \\
\pm 1.411\end{array}$ & $\begin{array}{r}19.58 \\
\pm 1.371\end{array}$ & $\begin{array}{c}24.26 \\
\pm 1.698\end{array}$ & $\begin{array}{c}25.56 \\
\pm 1.789\end{array}$ & $\begin{array}{c}33.46 \\
\pm 2.342\end{array}$ & $\begin{array}{c}28.36 \\
\pm 1.985\end{array}$ \\
\hline 13 & $\begin{array}{r}19.28 \\
\pm 1.157\end{array}$ & $\begin{array}{c}19.18 \\
\pm 1.151\end{array}$ & $\begin{array}{c}22.48 \\
\pm 1.349\end{array}$ & $\begin{array}{c}21.18 \\
\pm 1.271\end{array}$ & $\begin{array}{c}22.16 \\
\pm 1.330\end{array}$ & $\begin{array}{c}23.12 \\
\pm 1.387\end{array}$ & $\begin{array}{c}38.18 \\
\pm 2.291\end{array}$ & $\begin{array}{c}32.36 \\
\pm 1.942\end{array}$ \\
\hline 15 & $\begin{array}{c}22.58 \\
\pm 1.129\end{array}$ & $\begin{array}{c}22.46 \\
\pm 1.123\end{array}$ & $\begin{array}{c}24.88 \\
\pm 1.244\end{array}$ & $\begin{array}{c}23.16 \\
\pm 1.158\end{array}$ & $\begin{array}{c}24.18 \\
\pm 1.209\end{array}$ & $\begin{array}{c}25.42 \\
\pm 1.271\end{array}$ & $\begin{array}{c}44.82 \\
\pm 2.241\end{array}$ & $\begin{array}{c}38.76 \\
\pm 1.938\end{array}$ \\
\hline
\end{tabular}

$\alpha$-Amylase and $\beta$-amylase are the two amylases in plant tissues capable of metabolizing starch, $\alpha$-Amylase hydrolyze the $\alpha$-1,4-linkages of amylase at random to produce a mixture of glucose and maltose, whereas $\beta$-amylase attacks only the penultimate linkage from the non-reducing end and thus releases only maltose. These enzymes are unable to degrade the $\beta$ - (1-6) branch points of amylopectin, which are catalyzed by debranching enzymes. Amylase activity increases to some extent during ripening of many fruits (Fuchs et al., 1980; Tucker and Grierson, 1987).

Mango and banana are the major starch containing fruits ( -15 to $20 \%$, on fresh weight basis), where starch is almost completely hydrolyzed to free sugars, thus contributing to loosening of the all structure and textural softening during ripening (Bhagyalakshmi et al., 2002). Jain et al. (2003) noticed a similar observation in Guava: the activity of $\alpha$ and $\beta$ amylase decreased throughout the process of ripening, suggesting that perhaps the activity of these enzymes in raw guava was sufficient to hydrolyze starch during ripening which was 
apparent from the decrease in starch content during ripening. The highest activity of starchhydrolyzing enzymes was associated with the highest starch concentration.

\section{CONCLUSION}

Among the different 100, 200 and 300 ppm ethrel treatment the $200 \mathrm{ppm}$ alone had the optimum effect on the ripening of off-season fruits of Mangifera indica L. var Neelum.

\section{References}

[1] Selvaraj Y. (1993). Fruit ripening in Advances in Horticulture, Fruit Crops, (ed. K.L. Chadha and O.P. Pareek). Malhotra Publishing House, New Delhi, Vol.4, Part 4, 1703-1741.

[2] Bathgate B., Purton M. E., Grierson D. Goodenough P. W., Planta 165 (1985) 197-204.

[3] Loesecke H., Von W. (1949). Bananas, Interscience, Publishers, New York. p. 189.

[4] Presis J., Levi C. (1980). Starch biosynthesis and degradation. In: “The Biochemistry of Plants" - A comprehensive treatise. (ed. J. Preiss), Academic Press, vol. 13, 371-424.

[5] Jain N., Dhawan K., Malhotra S., Singh R., Pl. Fd. Human Nutr. 58 (2003) 309-315.

[6] Thanaraj T., Terry L. A., Bessant C., J. Fd. Chem. 112 (2009) 786-794.

[7] Paul A. A., Southgate D. A. T. (1978). The composition of Foods. HMSO. London, 418.

[8] Tandon D. K., Kalra S. K., J. Hort. Sci. 58(3) (1983) 449-453.

[9] Tandon D. K., Kalra S. K., Lohani H. C., Ind. J. Hort. 42 (1985) 223-228.

[10] Tucker G. A. (1993). Introduction in Biochemistry of Fruit Ripening. (ed. G. Seymour, J. Taylor and G. Tucker,) Chapman \& Hall, London, pp. 1-51.

[11] Yamaki S., Acta Hort. 398 (1995) 109-120.

[12] Venkitakrishnan M., Panjatcharam V., Kumaravelu G., Ramanujam M. P., Ind. J. Pl. Physiol. 2(4) (1997) 267-270.

[13] Lester G., J. Am. Soc. Hort. Sci. 23(1) (1998) 126-129.

[14] Subramanyam H., Narayanamoorthy N. V., Lakshmi-narayana S., Santha K., Acta Hort. 24 (1972) 260-264.

[15] Kalra S. K., Tandon D. K., Sci. Hort. 19 (1983) 263-269.

[16] Selvaraj Y., Kumar R., Pal D. K., J. Fd. Sci. Tech. 26 (1989) 308-313.

[17] Sacher J. A., Ann. Rev. Pl. Physiol. 24 (1973) 197-224.

[18] Mao and Kinsella, Fd. Sci. 46 (1981) 1400-1403.

[19] Desai B. B., Deshpande P. B., Mysore J. Agri. Sci. 12 (1978) 193-201. 
[20] Parikh H. R., Nair G. M., Modi, V. V., Ann. Bot. 65 (1990) 121-127.

[21] Fuchs Y., Pesis E., Zauberman G., Sci. Hort. 13 (1980) 155-160.

[22] Peacock B. C., Brown B. I. (1984). Quality comparison of Several mango varieties. Proceedings First Australian Mango Research Workshop, pp. 334-339.

[23] Lam P. F., Ng K. H., Omar D., Talib Y. (1982). Physical, Physiological and Chemical changes of „Golek ${ }^{e e}$ after harvest. Proc. Workshop on Mango and Rambutan. ASEAN, Postharvest Training and Research Center, College, Languna, Philippines, pp. 96-112.

[24] Tucker G. A., Grierson D. (1987). Fruit ripening. In The Biochemistry of plants -A comprehensive treatise (ed. D. D. Davies), Academic Press, vol. 12, 265-318.

[25] Clegg K. M., Sci. Fd. Agri. 7 (1956) 40-44.

[26] Nelson N., J. Biol. Chem. 153 (1944) 375-380.

[27] Danielson C. E., Nature 160 (1947) 889.

[28] Englard S., Singer T. P., J. Biochem. 187 (1950) 213.

[29] Barnell H. R., Annals. Bot. 20 (1941) 607-645.

[30] Barnell H. R., Annals. Bot. 20 (1941) 607-645.

[31] Bhagyalakshmi N., Prabha T. N., Yashoda H. M., Prasanna V., Jagadeesh B. H., Tharanathan R. N., Acta Hort. 575 (2002) 717-724. 